Article

\title{
Diversity and Evolution of Viral Pathogen Community in Cave Nectar Bats (Eonycteris spelaea)
}

\author{
Ian H Mendenhall ${ }^{1} * \mathbb{1}$, Dolyce Low Hong Wen ${ }^{1,2}$, Jayanthi Jayakumar ${ }^{1}$, Vithiagaran Gunalan ${ }^{3}$, \\ Linfa Wang ${ }^{1}{ }^{\circledR}$, Sebastian Mauer-Stroh ${ }^{3,4}{ }^{(}$, , Yvonne C.F. Su ${ }^{1}$ and Gavin J.D. Smith ${ }^{1,5,6}$ \\ 1 Programme in Emerging Infectious Diseases, Duke-NUS Medical School, Singapore 169857, Singapore; \\ dolyce.low@u.nus.edu (D.L.H.W.); jayanthi.jayakumar@duke-nus.edu.sg (J.J.); \\ linfa.wang@duke-nus.edu.sg (L.W.); yvonne.su@duke-nus.edu.sg (Y.C.F.S.) \\ gavin.smith@duke-nus.edu.sg (G.J.D.S.) \\ 2 NUS Graduate School for Integrative Sciences and Engineering, National University of Singapore, \\ Singapore 119077, Singapore \\ 3 Bioinformatics Institute, Agency for Science, Technology and Research, Singapore 138671, Singapore; \\ vithiagarang@bii.a-star.edu.sg (V.G.); sebastianms@bii.a-star.edu.sg (S.M.-S.) \\ 4 Department of Biological Sciences, National University of Singapore, Singapore 117558, Singapore \\ 5 SingHealth Duke-NUS Global Health Institute, SingHealth Duke-NUS Academic Medical Centre, \\ Singapore 168753, Singapore \\ 6 Duke Global Health Institute, Duke University, Durham, NC 27710, USA \\ * Correspondence: ian.mendenhall@duke-nus.edu.sg
}

Received: 30 January 2019; Accepted: 7 March 2019; Published: 12 March 2019

\begin{abstract}
Bats are unique mammals, exhibit distinctive life history traits and have unique immunological approaches to suppression of viral diseases upon infection. High-throughput next-generation sequencing has been used in characterizing the virome of different bat species. The cave nectar bat, Eonycteris spelaea, has a broad geographical range across Southeast Asia, India and southern China, however, little is known about their involvement in virus transmission. Here we investigate the diversity and abundance of viral communities from a colony of Eonycteris spelaea residing in Singapore. Our results detected 47 and 22 different virus families from bat fecal and urine samples, respectively. Among these, we identify a large number of virus families including Adenoviridae, Flaviviridae, Reoviridae, Papillomaviridae, Paramyxoviridae, Parvoviridae, Picornaviridae, and Polyomaviridae. In most cases, viral sequences from Eonycteris spelaea are genetically related to a group of bat viruses from other bat genera (e.g., Eidolon, Miniopterus, Rhinolophus and Rousettus). The results of this study improve our knowledge of the host range, spread and evolution of several important viral pathogens. More significantly, our findings provide a baseline to study the temporal patterns of virus shedding and how they correlate with bat phenological trends.
\end{abstract}

Keywords: Metaviromics; Southeast Asia; adenovirus; bunyavirus; flavivirus; herpesvirus; papillomavirus; paramyxovirus; parvovirus; picornavirus; polyomavirus; poxvirus; reovirus; rotavirus

\section{Introduction}

The advent of next generation sequencing (NGS) technologies has drastically increased the discovery of novel viruses and estimates of virus diversity [1,2]. Though family-level specific primers are often used to screen diagnostic samples, they are designed based on available reference sequences and typically target the most conserved genetic region such as the polymerase genes [3-5]. These assays often lack sensitivity at the expense of detecting an entire family of viruses. Next generation sequencing can detect viruses at low concentrations and often provides sequence reads from across the entire genome, providing sites for primer walking and gap closing [6-8]. This approach can also detect 
divergent lineages that may not be amplified using traditional polymerase chain reaction (PCR) approaches [9]. However, as host and bacterial components can dominate sequencing reads, virus reads of interest tend to be in low abundance in these data sets [10].

NGS has been employed to detect zoonotic pathogens and in numerous cases of virus discovery and metavirome descriptions, including bats in China, Myanmar, New Zealand and North America [11-15]. This technique has also detected novel poxviruses and adenoviruses, divergent papillomaviruses, and unique paramyxoviruses [16-18]. More recently, genetic regions from a novel filovirus were identified from Rousettus bat in China in 2015, indicating the utility of this approach to ascertain the presence of potentially pathogenic viruses in reservoir hosts [19].

Increasingly, these studies have focused on bats because this group of animals are unique virus reservoirs. Bats are distinctive mammals, having ecological, immunological and behavioral attributes that set them apart from other orders. Bats are exceptionally speciose, comprising $20 \%$ of all mammalian species and are the only mammals that are capable of true flight [20]. Many species are gregarious and roost in large colonies, which can number over one million individuals [21]. They are relatively long-lived for their body size and temperate species often undergo torpor or hibernation [22]. There are several theories regarding why bats are exceptional viral reservoirs and rarely experience pathogenesis with infection. One is that they have to deal with the physiological stress of flight, with increased metabolic rates and a subsequent increase in reactive oxygen species $[23,24]$. Recent research demonstrated that the unique innate immune system of bats may allow them to co-exist with viruses, maintaining very low levels of viremia or keeping viruses in a quiescent state [25-27].

Eonycteris spelaea is a nectivorous bat with a distribution ranging from the Malay-Indonesian archipelago to southern China, extending west into the Indian subcontinent [28]. These cave-roosting bats are especially important pollinators of durian [29]. There are two known colonies of E. spelaea in Singapore and both populations are restricted to roosting under bridges. This species forage at distances greater than $30 \mathrm{~km}$ from their roosting site, but are threatened across their range by habitat loss and hunting for human consumption [30]. Here we perform next generation sequencing on pooled feces and pooled urine samples collected from one colony of E. spelaea to identify the viral diversity and to examine the difference in virus communities between fecal and urine samples. Furthermore, we conducted phylogenetic analysis to understand the evolutionary relationships of different families of viruses detected from this study.

\section{Material and Methods}

\subsection{Sample Collection for NGS Library Preparation}

Urine and fecal samples were collected from 3 time points from a colony of the cave nectar bats (Eonycteris spelaea) in Singapore for NGS. Feces were collected on 14 March, 28 March and 11 April 2013 while urine was collected on 24 April, 8 May and 20 May 2014. Disposable plastic drop cloths were placed under the colony and approximately $25 \mathrm{~g}$ of feces was collected and placed in a $50-\mathrm{mL}$ tube. Urine samples from approximately 100 bats was placed into viral transport media (penicillin, streptomycin, polymyxin B, gentamicin, nystatin, olfoxacin, sulfamethoxazole). Fecal material was prepared for library preparation as previously described [31] while urine was centrifuged at 10,000 $\times \mathrm{g}$ for $3 \mathrm{~min}$ to pellet debris. RNA-zol was added to urine viral supernatant and RNA extracted using Direct-zol ${ }^{\mathrm{TM}}$ RNA MiniPrep (Zymo Research Corporation, Irvine, CA, USA), then subjected to in-column DNase I digestion (New England BioLabs Inc., Ipswich, MA, USA). Extracted and DNase I digested RNA was treated with Ribo-Zero ${ }^{\mathrm{TM}}$ Gold rRNA Removal Kit (Epidemiology) (Epicentre, Madison, WI, USA) and 500 bp cDNA libraries were constructed using NEBNext ${ }^{\circledR}$ Ultra $^{\text {TM }}$ Directional RNA Library Prep Kit for Illumina ${ }^{\circledR}$ (New England BioLabs Inc., Ipswich, MA, USA) and visualized on 1.5\% agarose gel, before being excised and purified using Zymoclean Gel DNA Recovery Kit (Zymo Research Corporation, Irvine, CA, USA). All sequencing reactions were run at the Duke-NUS Genome Biology Facility. Libraries from urine were run on an Illumina MiSeq machine with 
paired ends and a read length of $2 \times 250 \mathrm{bp}$, while fecal sample libraries were processed as described previously and run on an Illumina HiSeq 2000 with paired ends and a read length of $2 \times 76 \mathrm{bp}$.

\subsection{NGS Data Analysis}

All FASTQ files were assessed using FastQC to assess overall quality [32]. Trimming was executed using Trimmomatic-0.3.2 to remove adapters, low quality bases $(\mathrm{Q}=20$ with a sliding window 4$)$ and reads with fewer than $50 \mathrm{bp}$ length [33]. Taxonomic read classification was performed with DIAMOND sequence similarity searches against a local National Center for Biotechnology Information (NCBI) $\mathrm{nr}$ (non-redundant) protein database [34]. DIAMOND outputs were imported into MEGAN6 for the taxonomic binning of reads and visualizing the distribution of virus family reads [35]. X174 phage reads were removed from the final data set as these are spiked-in as control for the next generation sequencing reaction. Virus family reads were exported for phylogenetic analysis. To confirm whether the reads sorted by MEGAN were true positives, these were verified as viral hits using the BLASTX tool from the National Center of Biotechnology Information.

\subsection{Sample Collection and PCR Assays for Detection of Specific Viruses}

Individual urine samples were collected from 59 time points and pooled by date (2014-03-27 to 2016-09-01). Pooled Eonycteris urine samples were centrifuged at 10,000 $\times g$ for $1 \mathrm{~min}$. RNA was extracted from the supernatant using QIAamp ${ }^{\circledR}$ Viral RNA Mini Kit (\#52906; Qiagen Duesseldorf, Germany) and cDNA made with Random Hexamers and SuperScript ${ }^{\circledR}$ II Reverse Transcriptase (\#18064-014, Invitrogen, CA, USA). This was used to screen for orthoreovirus and paramyxovirus RNA-dependent RNA polymerase (RdRp) gene with family-specific primers [5,36]. PCR products were visualized on a $1.5 \%$ agarose gel, and $500 \mathrm{bp}$ bands from the paramyxovirus assay and $240 \mathrm{bp}$ bands from the orthoreovirus assay were excised, gel purified with Qiagen QIAquick Gel Purification kit and sent for Sanger sequencing with both forward and reverse reads sequenced ( $1^{\text {st }}$ Base DNA Sequencing Services, Axil Scientific Pte Ltd., Singapore).

\subsection{Phylogenetic Analysis}

Candidate reads from mammalian-specific viruses were de novo assembled in Geneious 7.1.6 (Biomatters Ltd., Auckland, New Zealand) and consensus sequences were used for subsequent phylogenetic analysis [37]. Representative nucleotide sequences specific to the gene of interest were downloaded from the NCBI GenBank for the following virus families (Table 1): Adenoviridae, Flaviviridae, Reoviridae, Papillomaviridae, Paramyxoviridae, Parvoviridae, Picornaviridae, and Polyomaviridae. For each viral family, individual sequence data sets were aligned using Transalign [38] and MAFFT [39] followed by manual curation of alignments. Gene phylogenies were initially reconstructed using FastTree [40], and the final data sets were further down sampled to reduce redundant and similar sequences. Altogether, 15 individual data sets were analyzed based on the following viral genes: adenovirus polymerase, flavivirus envelope, flavivirus NS5, paramyxovirus nucleoprotein, paramyxovirus polymerase, parvovirus VP1, parvovirus VP2, picornavirus 3D, picornavirus polyprotein, orthoreovirus M2, orthoreovirus L2, rotavirus VP1, rotavirus VP7, polyomavirus VP2, and 36 papillomavirus E1 (Table 1). Individual gene phylogenies were reconstructed using RAxML [41] with a general time reversible model and robustness of the nodes was assessed using 1000 bootstrap replicates. 
Table 1. Virus family alignments and sequence lengths.

\begin{tabular}{|c|c|c|c|c|}
\hline $\begin{array}{l}\text { Virus Family } \\
\text { (Genus) }\end{array}$ & Gene & $\begin{array}{l}\text { Initial Sequence } \\
\text { Alignment }\end{array}$ & $\begin{array}{c}\text { Down Sampled } \\
\text { Sequence Alignment }\end{array}$ & $\begin{array}{c}\text { Down Sampled } \\
\text { Alignment Length (bp) }\end{array}$ \\
\hline Adenoviridae & DNA Polymerase & 227 & 37 & 885 \\
\hline \multirow{2}{*}{ Flaviviridae } & E-Envelope & 398 & 45 & 333 \\
\hline & NS5-Non-structural protein 5 & 600 & 47 & 231 \\
\hline Papillomaviridae & V3-minor capsid protein & 368 & 36 & 969 \\
\hline \multirow{2}{*}{ Paramyxoviridae } & N-Nucleoprotein & 15 & 14 & 720 \\
\hline & L-Polymerase & 743 & 32 & 471 \\
\hline \multirow{2}{*}{ Parvoviridae } & VP1-Capsid & 27 & 20 & 528 \\
\hline & VP2-Capsid & 501 & 28 & 323 \\
\hline \multirow{2}{*}{ Picornaviridae } & 3D-RNA polymerase & 1753 & 20 & 246 \\
\hline & Polyprotein & 40 & 23 & 813 \\
\hline Polyomaviridae & E1-major capsid protein & 289 & 26 & 441 \\
\hline \multirow{2}{*}{$\begin{array}{c}\text { Reoviridae } \\
\text { (Orthoreovirus) }\end{array}$} & $\begin{array}{l}\text { M2-viral outer capsid proteins } \\
\text { ( } \sigma 1 \text { and } \mu 1 \mathrm{c})\end{array}$ & 149 & 21 & 624 \\
\hline & L2-core spike protein $\lambda 2$ & 30 & 22 & 318 \\
\hline \multirow[t]{2}{*}{$\begin{array}{l}\text { Reoviridae } \\
\text { (Rotavirus) }\end{array}$} & $\begin{array}{l}\text { VP1-RNA-dependent RNA } \\
\text { polymerase }\end{array}$ & 501 & 15 & 231 \\
\hline & VP7-outer capsid protein & 536 & 25 & 291 \\
\hline
\end{tabular}

\section{Results}

\subsection{Next Generation Sequencing Analysis}

Four NGS data sets generated from the pooled urine and fecal samples: two libraries (Urine-25 and Urine-27) were constructed from pooled urine that were run on Illumina MiSeq, while two other libraries (Feces-MiSeq and Feces-HiSeq) from pooled feces were sequenced using Illumina MiSeq and HiSeq, respectively. For urine samples, a total of 5,126,632 reads from Urine-25 and 13,421,263 reads from Urine-27 were generated, and approximately $29.8 \%$ and $30.8 \%$ of respective reads could be assigned to known sequences in the GenBank nr database by DIAMOND (Table 2). For the fecal data set, a total of 68,584,413 reads from the Feces-HiSeq and 4,952,973 reads from the Feces-MiSeq were generated, but the percentage of assigned reads from the data sets differed dramatically $(5.8 \%$ from Feces-HiSeq and 75.7\% from Feces-MiSeq). The majority of assigned reads in the fecal and urine samples were from Eukaryota. Reads assigned to bacteria amounted to between 11.2-14.6\% of the four NGS data sets. Fungal sequences were rare in the urine data sets, but common in the fecal data sets, comprising $16.9 \%$ of assigned reads in Feces-HiSeq and 35.4\% of assigned reads in Feces-MiSeq. Viral reads were a relatively small component, totaling approximately $1 \%$ of all assigned reads from the four data sets. All NGS data sets are available at the National Center for Biotechnology Information Sequence Read Archive under bioProject PRJNA524946.

Our results detected 22 and 47 different virus families from urine and fecal samples of Eonycteris spelaea, respectively (Table 3). We observed differences in viral presence and absence between urine and fecal samples. There were 25 virus families were unique to the fecal data sets and seven of these are known to infect vertebrates: Bunyaviridae, Caliciviridae, Papillomaviridae, Parvoviridae, Picobirniviridae, Picornaviridae, and Rhabdoviridae. Moreover, the most common virus families found in the urine are retroviruses (25.38\% of total reads), dicistroviruses $(20.59 \%)$, and coronaviruses (15.22\%) (Table 3). The fecal samples virus reads were primarily dicistroviruses (58.1\%), which are arthropod-specific viruses with phenotypes ranging from asymptomatic infection to high mortality in insects [42]. Viruses in the families Siphoviridae (14.7\%) and Podoviridae (15.4\%), both bacteriophages, were commonly identified. Other viruses detected in the bat fecal samples included parvoviruses $(0.54 \%)$, retroviruses $(0.99 \%)$, reoviruses $(0.15 \%)$, picornaviruses $(0.14 \%)$, and polyomaviruses $(0.14 \%)$ (Table 3$)$. For the pooled urine screening from 2014-03-27 to 2016-09-01, a total of 15 samples (25.4\%) were positive for paramyxoviruses, while 1 sample $(1.7 \%)$ was positive for orthoreoviruses. 
Table 2. Next generation sequencing reads by data set and selected taxonomic ranks.

\begin{tabular}{ccccccccccc}
\hline Data set-Name & $\begin{array}{c}\text { Total Reads in } \\
\text { Data set }\end{array}$ & $\begin{array}{c}\text { Total Reads Assigned } \\
\text { by MEGAN }\end{array}$ & Eukaryotes & Mammalia & Arthropoda & Bacteria & Archaea & Fungi & Virus & \\
\hline Urine-MiSeq-25 & $5,126,632$ & $1,527,375$ & $1,154,068$ & $1,010,668$ & 583 & 222,953 & 204 \\
\hline Urine-MiSeq-27 & $13,421,263$ & $4,137,771$ & $3,230,684$ & $2,994,683$ & 1201 & 548,911 & 497 & 20,496 & 3691 \\
\hline Feces HiSeq & $68,584,413$ & $3,993,465$ & $2,178,408$ & 69,136 & 53,546 & 546,757 & 68 & 675,967 & 21,856 \\
\hline Feces MiSeq & $4,952,973$ & $3,750,870$ & $2,836,374$ & 54,457 & 60,533 & 420,446 & 97 & $1,326,425$ & 106,823 \\
\hline
\end{tabular}

Table 3. Virus reads from next generation sequencing data set from Eonycteris spelaea urine and feces.

\begin{tabular}{|c|c|c|c|c|c|c|c|c|}
\hline Virus Family & $\begin{array}{l}\text { Urine-MiSeq-25 } \\
\text { Reads }\end{array}$ & $\begin{array}{l}\text { Urine-MiSeq-27 } \\
\text { Reads }\end{array}$ & $\begin{array}{c}\text { Urine reads by } \\
\text { Family (\% of Total) }\end{array}$ & $\begin{array}{l}\text { Feces-Hiseq } \\
\text { Reads }\end{array}$ & $\begin{array}{c}\text { Feces-MiSeq } \\
\text { Reads }\end{array}$ & $\begin{array}{c}\text { Fecal Reads by } \\
\text { Family (\% of Total) }\end{array}$ & Total Reads & $\begin{array}{c}\text { Consensus } \\
\text { Reads/Unassembled Reads }\end{array}$ \\
\hline Adenoviridae $\mathrm{V}$ & 171 & 115 & $286(7.14 \%)$ & 31 & 43 & $74(0.07 \%)$ & $360(0.31 \%)$ & $28 / 17$ \\
\hline Alphaflexiviridae $\mathrm{P} / \mathrm{F}$ & - & - & - & - & 143 & $143(0.13 \%)$ & $143(0.12 \%)$ & $28 / 13$ \\
\hline Alphatetraviridae ${ }^{\mathrm{A}}$ & - & - & - & - & 1 & 1 & 1 & - \\
\hline Astroviridae $\mathrm{V}$ & 50 & - & $50(1.25 \%)$ & 6 & 8 & $14(0.01 \%)$ & $64(0.05 \%)$ & $6 / 3$ \\
\hline Baculoviridae $^{\mathrm{A}}$ & - & - & - & 1 & 2 & 3 & 3 & $0 / 3$ \\
\hline Betaflexiviridae $^{\mathrm{P} / \mathrm{F}}$ & 4 & - & $4(0.10 \%)$ & 9 & 14 & $23(0.02 \%)$ & $27(0.02 \%)$ & $7 / 9$ \\
\hline Bunyaviridae $\mathrm{V}$ & - & - & - & - & 1 & 1 & 1 & - \\
\hline Caliciviridae $^{\mathrm{V}}$ & - & - & - & - & 9 & $9(0.01 \%)$ & $9(0.01 \%)$ & $4 / 1$ \\
\hline Carmotetraviridae $^{\mathrm{A}}$ & - & - & - & - & 34 & $34(0.03 \%)$ & $34(0.03 \%)$ & $5 / 0$ \\
\hline Caulimoviridae $^{\mathrm{A} / \mathrm{P}}$ & - & - & - & 3 & 5 & $8(0.01 \%)$ & $8(0.01 \%)$ & $2 / 4$ \\
\hline Chrysoviridae $\mathrm{F}$ & 15 & - & $15(0.37 \%)$ & 3 & 3 & $6(0.01 \%)$ & $21(0.02 \%)$ & $5 / 2$ \\
\hline Coronaviridae $^{\mathrm{V}}$ & 170 & 440 & $610(15.22 \%)$ & 46 & 87 & $133(0.12 \%)$ & $743(0.64 \%)$ & $52 / 21$ \\
\hline Dicistroviridae $^{\mathrm{A}}$ & 120 & 705 & $825(20.59 \%)$ & 292 & 65,061 & $65,353(58.09 \%)$ & $66,178(56.80 \%)$ & $2326 / 1546$ \\
\hline Endornaviridae $^{\mathrm{P} / \mathrm{F}}$ & - & - & - & - & 4 & 4 & 4 & $2 / 0$ \\
\hline Flaviviridae $\mathrm{V}^{\mathrm{V}}$ & 10 & 52 & $62(1.55 \%)$ & - & 1 & 1 & $63(0.05 \%)$ & $2 / 1$ \\
\hline Herpesviridae $^{\mathrm{V}}$ & 25 & - & $25(0.62 \%)$ & 3 & 12 & $15(0.01 \%)$ & $40(0.03 \%)$ & $7 / 5$ \\
\hline Iflaviridae $\mathrm{A}$ & 8 & - & $8(0.20 \%)$ & 46 & 578 & $624(0.55 \%)$ & $632(0.54 \%)$ & $79 / 21$ \\
\hline Inoviridae $\mathrm{B}$ & - & - & - & 1 & - & 1 & 1 & - \\
\hline
\end{tabular}


Table 3. Cont.

\begin{tabular}{|c|c|c|c|c|c|c|c|c|}
\hline Virus Family & $\begin{array}{l}\text { Urine-MiSeq-25 } \\
\text { Reads }\end{array}$ & $\begin{array}{l}\text { Urine-MiSeq-27 } \\
\text { Reads }\end{array}$ & $\begin{array}{c}\text { Urine reads by } \\
\text { Family (\% of Total) }\end{array}$ & $\begin{array}{l}\text { Feces-Hiseq } \\
\text { Reads }\end{array}$ & $\begin{array}{l}\text { Feces-MiSeq } \\
\text { Reads }\end{array}$ & $\begin{array}{c}\text { Fecal Reads by } \\
\text { Family (\% of Total) }\end{array}$ & Total Reads & $\begin{array}{c}\text { Consensus } \\
\text { Reads/Unassembled Reads }\end{array}$ \\
\hline Leviviridae ${ }^{\mathrm{B}}$ & - & - & - & - & 4 & 4 & 4 & $2 / 0$ \\
\hline Luteoviridae $^{\mathrm{P}}$ & - & - & - & - & 1 & 1 & 1 & - \\
\hline Microviridae $^{\mathrm{B}}$ & 17 & 117 & $134(3.34 \%)$ & 3016 & 438 & $3454(3.07 \%)$ & $3588(3.08 \%)$ & $39 / 8$ \\
\hline Mimiviridae $^{\mathrm{PR}}$ & - & - & - & - & 1 & 1 & 1 & - \\
\hline Myoviridae $^{\mathrm{B}}$ & 1 & - & $1(0.02 \%)$ & 4029 & 1688 & $5717(5.08 \%)$ & $5718(4.91 \%)$ & $525 / 346$ \\
\hline Narnaviridae $^{\mathrm{F}}$ & - & - & - & 16 & 345 & $361(0.32 \%)$ & $361(0.31 \%)$ & $42 / 6$ \\
\hline Nodaviridae $^{\mathrm{A}}$ & - & - & - & - & 117 & $117(0.10 \%)$ & $117(0.10 \%)$ & $13 / 10$ \\
\hline Nudiviridae $^{\mathrm{A}}$ & - & - & - & 28 & 63 & $91(0.08 \%)$ & $91(0.08 \%)$ & $32 / 16$ \\
\hline Papillomaviridae $^{\mathrm{V}}$ & - & - & - & 3 & 9 & $12(0.01 \%)$ & $12(0.01 \%)$ & $3 / 3$ \\
\hline Paramyxoviridae $^{\mathrm{V}}$ & 14 & 34 & $48(1.20 \%)$ & 3 & 6 & $9(0.01 \%)$ & $57(0.05 \%)$ & $6 / 1$ \\
\hline Partitiviridae $^{\mathrm{P} / \mathrm{F}}$ & 12 & 129 & $141(3.52 \%)$ & 12 & 22 & $34(0.03 \%)$ & $175(0.15 \%)$ & $12 / 11$ \\
\hline Parvoviridae $\mathrm{V}$ & - & - & - & 203 & 421 & $624(0.55 \%)$ & $624(0.54 \%)$ & $55 / 21$ \\
\hline Genus: Parvovirinae & - & - & - & 187 & 370 & $557(0.50 \%)$ & $557(0.48 \%)$ & - \\
\hline Genus: Denovirinae & - & - & - & 8 & 51 & $59(0.05 \%)$ & $59(0.05 \%)$ & - \\
\hline Permutotetraviridae $\mathrm{A}$ & - & - & - & 55 & 933 & $988(0.88 \%)$ & $988(0.85 \%)$ & $92 / 7$ \\
\hline Phycodnaviridae $^{\mathrm{P}}$ & 3 & 1 & $4(0.10 \%)$ & - & 2 & 2 & $6(0.01 \%)$ & $1 / 3$ \\
\hline Picobirnaviridae $^{\mathrm{V}}$ & - & - & - & - & 3 & 3 & 3 & $0 / 3$ \\
\hline Picornaviridae $^{\mathrm{V}}$ & - & - & - & 45 & 114 & $159(0.14 \%)$ & $159(0.14 \%)$ & $33 / 17$ \\
\hline Podoviridae ${ }^{\mathrm{B}}$ & 26 & - & $26(0.65 \%)$ & 4002 & 13,349 & $17,351(15.42 \%)$ & $17,377(14.91 \%)$ & $787 / 225$ \\
\hline Polydnaviridae $\mathrm{A}$ & - & - & - & 4 & 6 & $10(0.01 \%)$ & $10(0.01 \%)$ & $3 / 4$ \\
\hline Polyomaviridae $\mathrm{V}$ & 8 & - & $8(0.20 \%)$ & 63 & 93 & $156(0.14 \%)$ & $164(0.14 \%)$ & $33 / 13$ \\
\hline Potyviridae $^{\mathrm{P}}$ & - & - & - & 44 & 15 & $59(0.05 \%)$ & $59(0.05 \%)$ & $13 / 12$ \\
\hline Poxviridae $^{\mathrm{V}}$ & 16 & - & $16(0.40 \%)$ & 2 & 1 & 3 & $19(0.02 \%)$ & $3 / 3$ \\
\hline Reoviridae $^{\mathrm{V}}$ & 1 & - & $1(0.02 \%)$ & 95 & 76 & $171(0.15 \%)$ & $172(0.15 \%)$ & $42 / 22$ \\
\hline Genus: Orthoreovirus & 1 & - & 1 & 53 & 25 & $78(0.07 \%)$ & $103(0.09 \%)$ & - \\
\hline Genus: Rotavirus & - & - & - & 24 & 39 & $63(0.06 \%)$ & $102(0.09 \%)$ & - \\
\hline
\end{tabular}


Table 3. Cont

\begin{tabular}{|c|c|c|c|c|c|c|c|c|}
\hline Virus Family & $\begin{array}{l}\text { Urine-MiSeq-25 } \\
\text { Reads }\end{array}$ & $\begin{array}{l}\text { Urine-MiSeq-27 } \\
\text { Reads }\end{array}$ & $\begin{array}{c}\text { Urine reads by } \\
\text { Family (\% of Total) }\end{array}$ & $\begin{array}{l}\text { Feces-Hiseq } \\
\text { Reads }\end{array}$ & $\begin{array}{l}\text { Feces-MiSeq } \\
\text { Reads }\end{array}$ & $\begin{array}{c}\text { Fecal Reads by } \\
\text { Family (\% of Total) }\end{array}$ & Total Reads & $\begin{array}{c}\text { Consensus } \\
\text { Reads/Unassembled Reads }\end{array}$ \\
\hline Retroviridae $\mathrm{V}$ & 552 & 465 & $1017(25.38 \%)$ & 95 & 39 & $134(0.12 \%)$ & 1151 (0.99\%) & $170 / 61$ \\
\hline Rhabdoviridae ${ }^{\mathrm{A}}$ & - & - & - & - & 11 & $11(0.01 \%)$ & $11(0.01 \%)$ & $4 / 2$ \\
\hline Secoviridae ${ }^{\mathrm{P}}$ & - & 87 & $87(2.17 \%)$ & - & 33 & $33(0.03 \%)$ & $120(0.10 \%)$ & $6 / 2$ \\
\hline Siphoviridae ${ }^{\mathrm{B}}$ & 17 & 325 & $342(8.54 \%)$ & 8839 & 7662 & $16,501(14.67 \%)$ & $16,843(14.46 \%)$ & $518 / 144$ \\
\hline Totiviridae V/A/P & 16 & 281 & $297(7.41 \%)$ & - & 47 & $47(0.04 \%)$ & $344(0.30 \%)$ & $23 / 12$ \\
\hline Tymoviridae $^{\mathrm{P}}$ & - & - & - & 1 & 8 & $9(0.01 \%)$ & $9(0.01 \%)$ & $3 / 1$ \\
\hline Virgaviridae $^{\mathrm{P}}$ & - & - & - & - & 2 & 2 & 2 & $1 / 0$ \\
\hline Total Reads & 1256 & 2751 & 4007 & & 20,996 & & 116,518 & \\
\hline
\end{tabular}

V = Vertebrate; $\mathrm{A}=$ Arthropod; $\mathrm{P}$ = Plant; F = Fungi; $\mathrm{B}=$ Bacteria; $\mathrm{PR}$ = Protist 


\subsection{Adenoviridae}

Of the 360 total adenovirus reads from the fecal and urine data sets, there were 39 contigs assembled with 17 reads unassembled. The longest contig was $539 \mathrm{bp}$, while the shortest was $115 \mathrm{bp}$. A 504 bp contig was similar to the mamadenovirus polymerase genes. The polymerase phylogeny (Figure S1) of adenovirus clearly indicates Eonycteris adenovirus is well nested within a monophyletic clade (72\% bootstrap support, BS) of bat adenovirus from Rousettus and Minopterus species. The new adenovirus sequence from Singapore (MK603133) is most closely related to two Rousettus leschenaultii adenovirus sequences (KX961095 and KX961096) from China in 2013. They share a high level of nucleotide (nt: $86.6 \%$ ) and amino acid (aa: 99.4\%) similarities.

\subsection{Flaviviridae}

Two contigs were assembled from 62 flavivirus reads from the fecal and urine data sets. These were mapped to an envelope (E) protein and a NS5 protein, which encodes methyltransferase and RNA-dependent RNA polymerase, respectively. The E phylogeny (Figure S2) of Flavivirus indicates that the Eonycteris sequence (MK603134) closely resembles Phnom Penh virus from a Cynopterus bat (NC_034007), with $88.4 \%$ nucleotide (nt) similarity and $92.7 \%$ amino acid (aa) similarity. They formed a strongly supported monophyletic clade (100\% BS) with Batu Cave virus from Malaysia (KJ469370). Similar observations are found in the NS5 phylogeny (Figure S2), although the Eonycteris sequence (MK603135) appears to be more closely related to Batu Cave virus (58\% BS; nt: $92.5 \%$, aa: $100 \%$ similarity).

\subsection{Reoviridae}

The 172 reovirus reads from the fecal data set were assembled into 41 contigs with 23 unassembled reads. The longest contig was $487 \mathrm{bp}$, while the shortest was $76 \mathrm{bp}$. There were members of the genera Orthoreovirus and Rotavirus in the data set. Four contigs were selected for phylogenetic reconstruction. Two contigs (206 bp and 199bp) were similar to the orthoreovirus M2 gene, which encodes the viral outer capsid proteins $(\sigma 1$ and $\mu 1 \mathrm{c})$ involved in receptor binding and host cell membrane penetration. The M2 (624bp) phylogeny (Figure 1) of orthoreovirus revealed the Eonycteris sequence (MK603137) is most closely related to Melaka virus from Malaysia (JF342664) with $98.5 \%$ amino acid (aa) similarity and $97.2 \%$ nucleotide (nt) similarity. We also detected a 318-bp contig of the L1 gene of reovirus sequences. This gene encodes the RNA dependent RNA polymerase. The Eonycteris L1 sequence (MK603136) (Figure 1) is most closely related to Cangyuan orthoreovirus (KM382260) and Melaka orthoreovirus (JF342661), both with $100 \%$ aa similarity and $97.5 \%$ nt similarity. The Eoncyteris L1 segment also formed a strongly supported monophyletic clade (100\% BS) with other bat ortheroviruses, including; Melaka virus, Cangyuan virus (KM382260), Kampar virus (JF342655), Pulau virus (JF342667), Nelson Bay reovirus (JF342673) and Pteropine reovirus (KM279381).

The other Orthoreovirus contigs belong to the genus Rotavirus, with a $321 \mathrm{bp}$ contig similar to the VP1 gene or RNA-dependent RNA polymerase (RdRp) and the second contig (291 bp) mapping to the outer capsid protein sequence (VP7). The VP1 gene (Figure 2) of Eoncyteris rotavirus was most similar to rotavirus detected in a Rousettus leschenaultii from China in 2005 (KX814935), with an 76.6\% aa similarity and 73.5\% nt similarity. The Eonycteris and Rousettus sequences (MK603148) formed a well-supported monophyletic clade (99\% BS) (Figure 2). In contrast, the Rotavirus VP7 gene sequence from Eonycteris (MK603149) forms a polytomy with other rotavirus sequences from a broad range of hosts including humans, pigs, bovines and equines (Figure 2). 


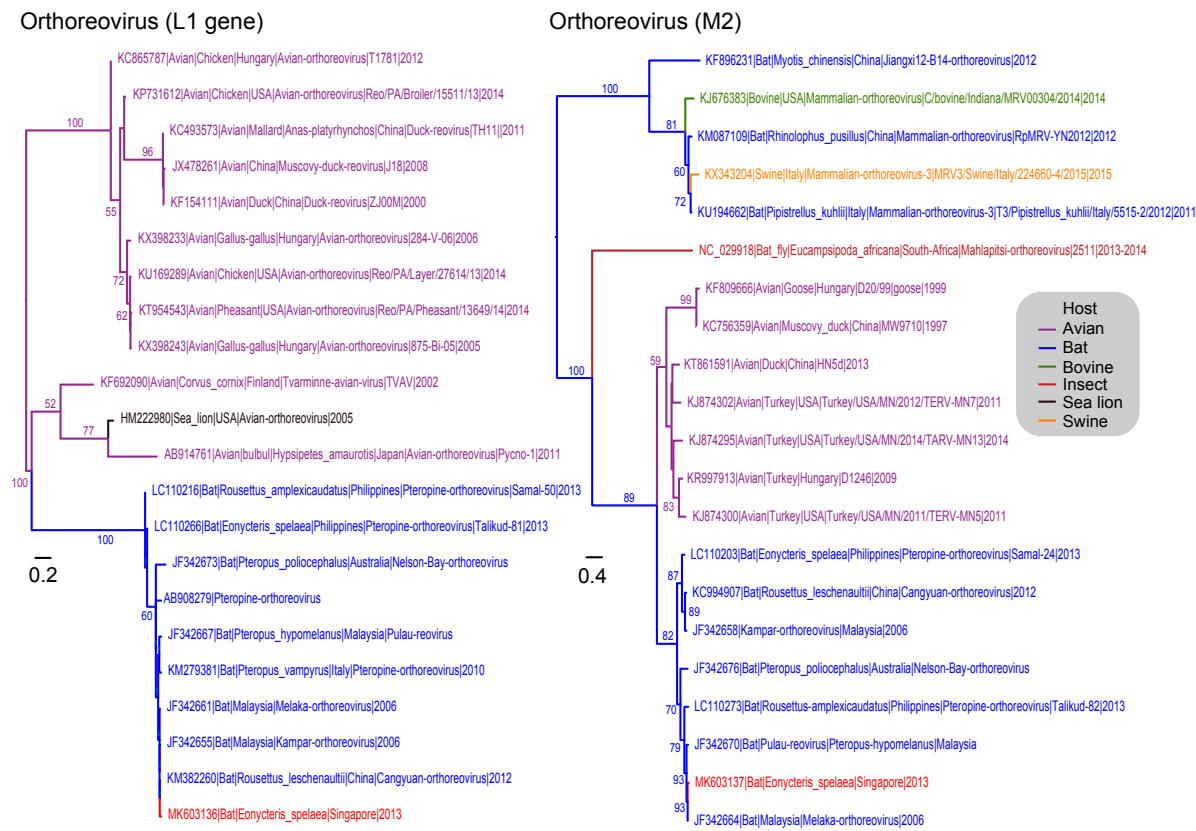

Figure 1. Phylogenetic relationships of the L1 and M2 gene sequences of orthoreovirus, inferred by using the maximum-likelihood method with the generalised time-reversible (GTR) + GAMMA distribution model in RAxML. Colored branches represent viruses isolated from different hosts. Red branches denote new sequences collected from Eonycteris spelaea bats in Singapore. Bootstrap support values greater than $50 \%$ are displayed at major nodes. The scale bar indicates the number of nucleotide substitutions per site.

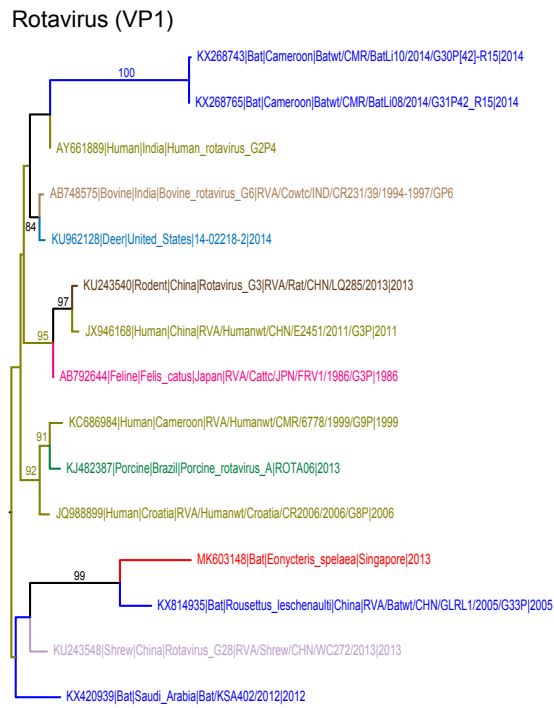

$\overline{0.2}$

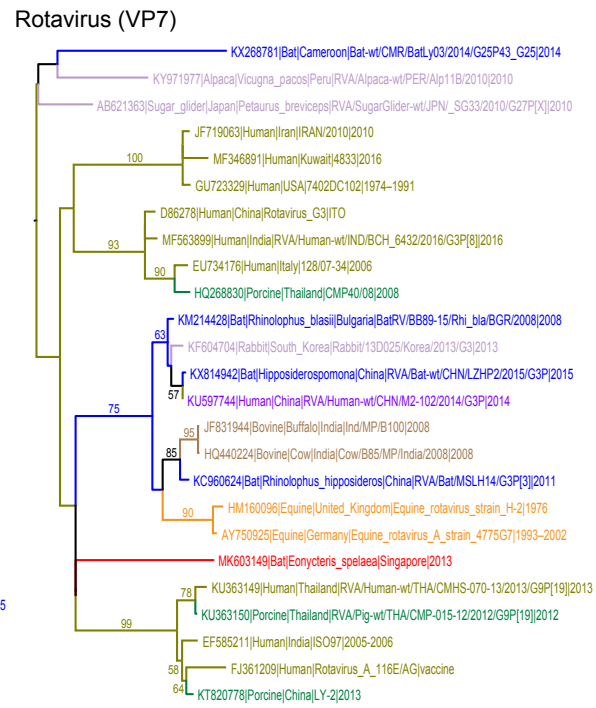

$\overline{0.05}$

$$
\begin{aligned}
& \text { Host }- \text { Bat }- \text { Deer }- \text { Feline }- \text { Porcine - Others } \\
& \text { Bovine - Equine }- \text { Human }- \text { Rodent }
\end{aligned}
$$

Figure 2. Phylogenetic relationships of the VP1 and VP7 gene sequences of rotavirus, inferred by using the maximum-likelihood method with the GTR + GAMMA model in RAxML. Colored branches represent viruses isolated from different hosts. Red branches denote new sequences collected from Eonycteris spelaea bats in Singapore. Bootstrap support values greater than $50 \%$ are displayed at major nodes. The scale bar indicates the number of nucleotide substitutions per site. 


\subsection{Papillomaviridae}

There were 12 papillomavirus reads from the fecal data set and 9 were assembled to produce 3 contigs (L1 protein and two E1 protein contigs), with a maximum length of $635 \mathrm{bp}$ and a minimum length of $77 \mathrm{bp}$. One contig (439 bp) was similar to the V3 gene which encodes the minor capsid protein. The papillomavirus E1 phylogeny (Figure S3) indicates the Eonycteris sequence (MK603138) is most similar to an Eidolon helvum papillomavirus from Cameroon (KX276956). These two sequences have $68.4 \%$ aa similarity and $69 \%$ nt similarity. These two sequences were in a monophyletic group with another Eidolon helvum papillomavirus from Cameroon (KX276957) (100\% BS).

\subsection{Paramyxoviridae}

There were 57 reads from the fecal and urine data sets were classified as from Paramyxoviridae of which 56 were assembled to produce 6 contigs. The longest contig was $338 \mathrm{bp}$ and the shortest was $127 \mathrm{bp}$ and there were sequences from the polymerase gene (L) and nucleocapsid (NP). From the family-specific PCR, there were two unique polymerase sequences generated (471 bp) with $61.8 \%$ aa similarity and $64.3 \% \mathrm{nt}$ similarity. The two L-gene contigs of Eonycteris (MK603139, MK603140) (Figure 3) were closely related to those from Eidolon helvum paramyxoviruses found in Ghana and Republic of the Congo. In comparison, two NP sequences (MK603141 and MK603142) (Figure 3) from Eonycteris (98.4\% aa similarity) are in a sister group to human henipaviruses and other bat borne paramyxoviruses $(74 \% \mathrm{BS})$.

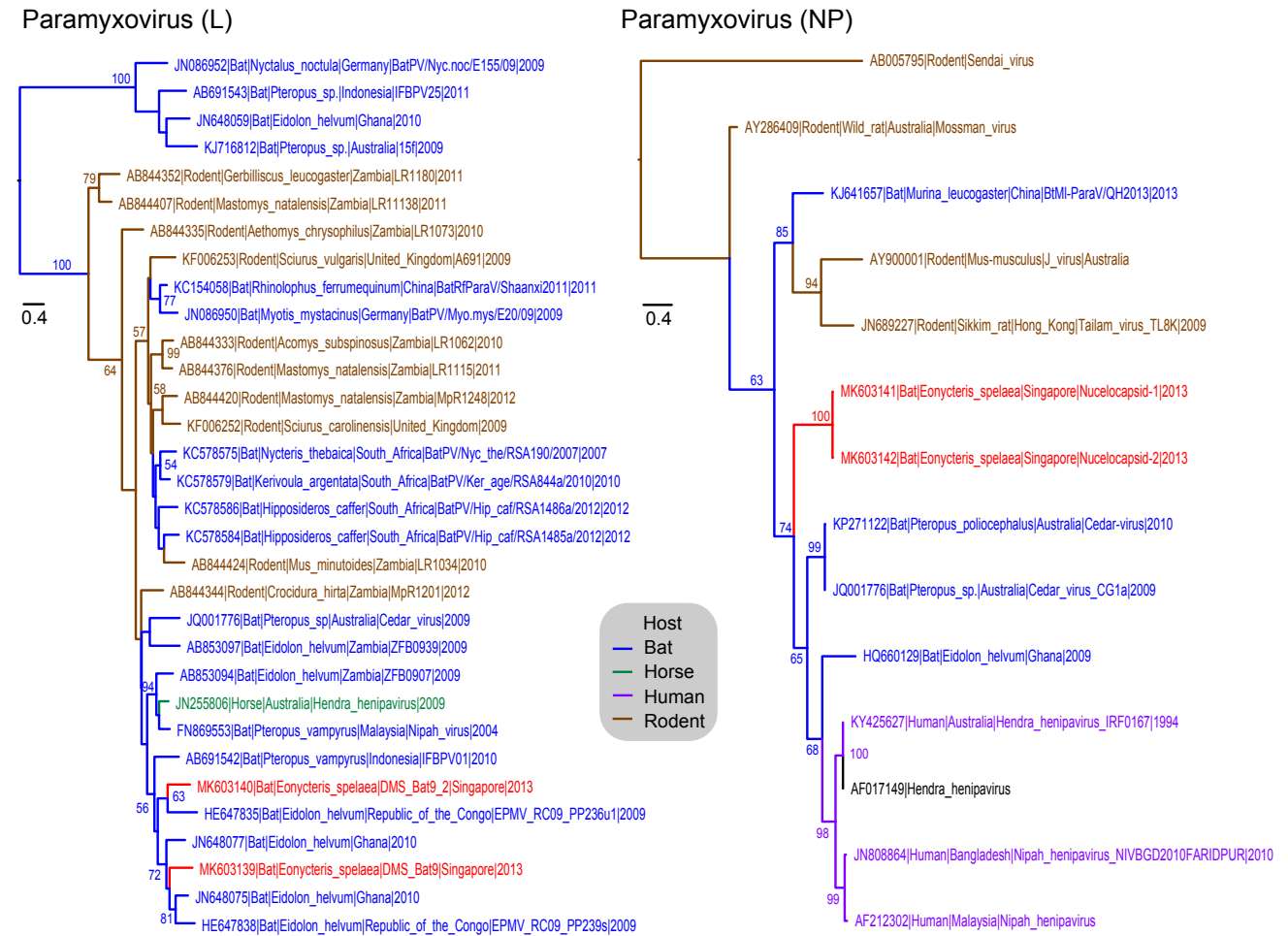

Figure 3. Phylogenetic relationships of the L and NP gene sequences of paramyxovirus, inferred by using the maximum-likelihood method with the GTR + GAMMA model in RAxML. Colored branches represent viruses isolated from different hosts. Red branches denote new sequences collected from Eonycteris spelaea bats in Singapore. Bootstrap support values greater than 50\% are displayed at major nodes. The scale bar indicates the number of nucleotide substitutions per site.

\subsection{Parvoviridae}

There were 565 Parvovirinae reads from the fecal data sets. These produced 43 contigs with a maximum length of $891 \mathrm{bp}$ and a minimum length of $120 \mathrm{bp}$. Two contigs matched with the 
capsid gene (VP1 and VP2) of parvovirus. The VP1 contig (321 bp) from Eonycteris (MK603143) is related to a Rousettus leschenaultii parvovirus from in China (100\% BS) (MF682925), and they shared a $73.5 \%$ nt similarity and $76.6 \%$ aa similarity. These two sequences also formed a strongly supported monophyletic clade with porcine bocaviruses (97\% BS) (Figure 4). Similar to the VP1 gene, the VP2 sequence (MK603144) (319 bp) from Eonycteris is sister to several porcine bocaviruses, forming a well-supported clade (87\% BS) (Figure 4).

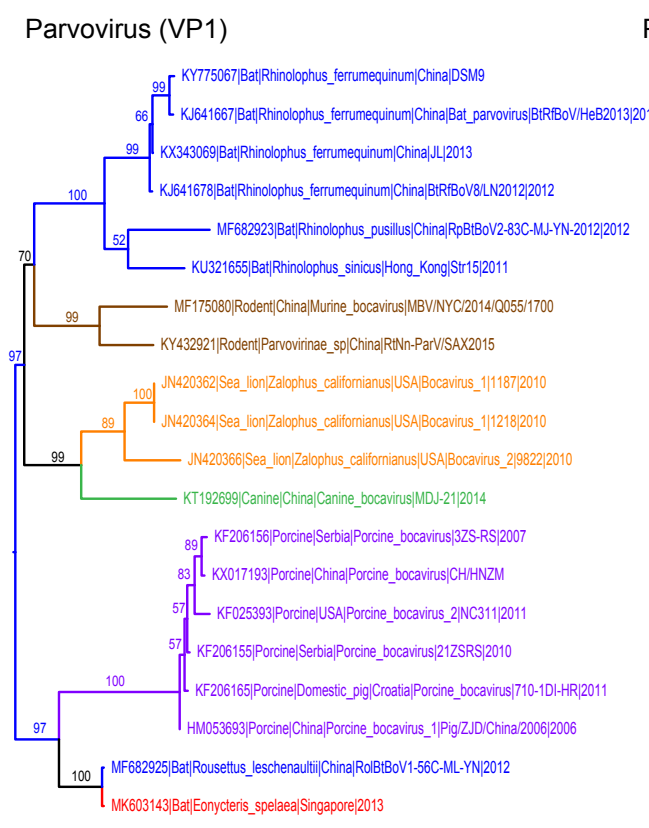

Parvovirus (VP2)

$\overline{0.1}$

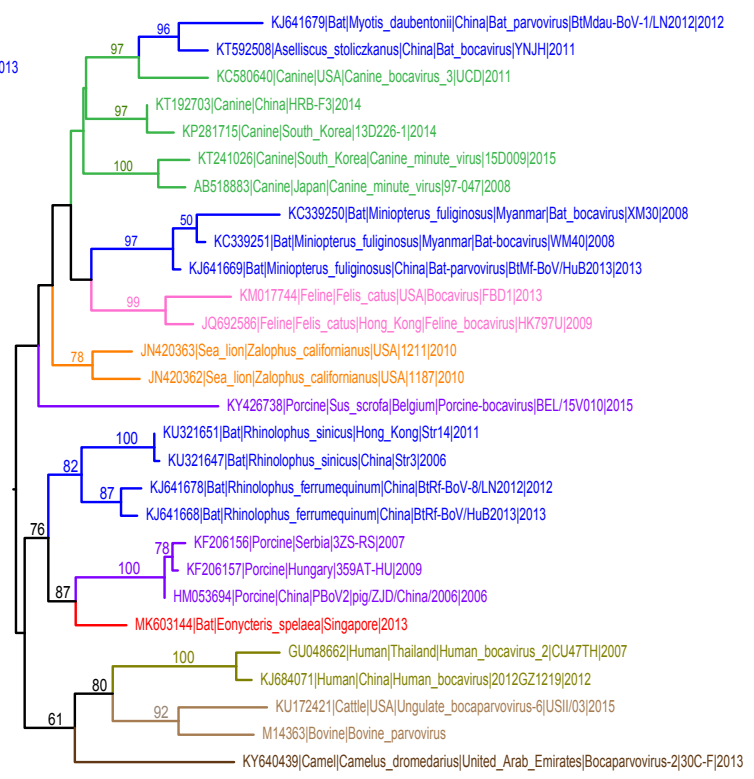

$\overline{0.2}$

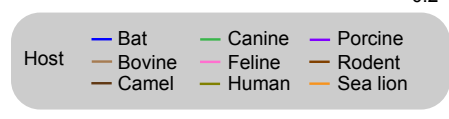

Figure 4. Phylogenetic relationships of the VP1 and VP2 gene sequences of parvovirus, inferred by using the maximum-likelihood method with the GTR + GAMMA model in RAxML. Colored branches represent viruses isolated from different hosts. Red branches denote new sequences collected from Eonycteris spelaea bats in Singapore. Bootstrap support values greater than $50 \%$ are displayed at major nodes. The scale bar indicates the number of nucleotide substitutions per site.

\subsection{Picornaviridae}

There were 159 reads from the fecal data sets classified in Picornaviridae. These created 33 contigs, the longest at $724 \mathrm{bp}$ and the shortest $76 \mathrm{bp}$. One contig was from the polyprotein region and picornavirus phylogeny (Figure S4) indicates the Eonycteris sequence (MK603145) was sister to a monophyletic clade (100\% BS) comprising three bat picornaviruses (KJ641693, HQ595345, NC_015934) from Rhinolophus hipposideros, R. sinicus and Hipposideros armiger from China and Hong Kong. These shared a $68.4 \%$ nt similarity and a $51.7 \%$ aa similarity. Another read matched the 3D gene that encodes for RNA polymerase. The 3D gene from Eonycteris (MK603146) (Figure S4) was related to bat picornavirus from Vespertilio superans and Myotis altarium from China $(72.8 \% \mathrm{nt}$ and $79.2 \%$ aa similarity), although this node was not statistically supported.

\subsection{Polyomaviridae}

A total of 164 reads from the fecal and urine data sets were assigned to the virus family Polyomaviridae and 33 contigs were assembled. The shortest contig was $89 \mathrm{bp}$ and the longest was $525 \mathrm{bp}$. One read of $420 \mathrm{bp}$ was from the VP2 major capsid gene. The VP2 of polyomavirus phylogeny (Figure S5) indicates the Eonycteris sequence (MK603147) forms a strongly supported monophyletic clade $(100 \%$ BS) with a bat polyomavirus from Hipposideros pomona from China (nt: $91.7 \%$ similarity 
and aa: $97.1 \%$ similarity). In addition, it is apparent that polyomavirus is capable of infecting diverse species of different bat families, including Miniopteridae (e.g., Miniopterus and Myotis), Molossidae (e.g., Otomops), Pteropodidae (e.g., Acerodon, Dohsonia, Eidolon, Rousettus), Phyllostomidae (e.g., Artibeus), and Rhinolophidae (e.g., Rhinolopus).

\subsection{Additional Viruses Detected}

In addition to the above-mentioned viruses identified from fecal and urine samples of Eonycteris bats in Singapore, there were other virus families with a low number of reads $(<15)$. For instance, one read (114 bp) was identified as a bunyavirus sequence that is most similar to the $\mathrm{L}$ protein of phlebovirus found in blacklegged ticks. Three reads corresponded to Taterapox virus (Poxviridae), originally isolated from an African gerbil and 15 reads for herpesviruses. Phylogenetic relationships of these viral pathogens were not reconstructed due to a lack of reference sequences in GenBank.

Notably, insect viruses and plant/fungal viruses were frequently identified in our bat samples from Singapore. The most common invertebrate viruses were dicistroviruses (65,353 reads), but there were several other virus families present (Alphatetraviridae, Balculoviridae, Carmotetraviridae, Caulimoviridae, Nodaviridae, Nudiviridae, Permutotetraviridae and Polydnaviridae). Moreover, detectable plant/fungal viruses include Alphaflexiviridae, Betaflexiviridae, Edornaviridae, Luteoviridae, Narnaviridae, Partitiviridae, Phycodnaviridae, Potyviridae, Secoviridae, Tymoviridae and Virgaviridae. Taken together, our study identifies a broad diversity of viruses present in Eonycteris bats in Singapore.

\section{Discussion}

This comparative metagenomic study reports the fecal and urine virome of the cave nectar bat, Eonycteris spelaea, in Singapore. Our NGS findings detected a broad diversity of viral pathogens present in Eonycteris bat species, with 43 and 22 different virus families from the fecal and urine samples, respectively. Among these, we identified a large number of virus families that commonly infect vertebrates, including Adenoviridae, Flaviviridae, Reoviridae, Papillomaviridae, Paramyxoviridae, Parvoviridae, Picornaviridae and Polyomaviridae. Previous virus surveillance on Eonycteris spelaea detected genomic evidence of astroviruses, coronaviruses and filoviruses with serologic evidence of filoviruses from Singapore and China [31,43,44]. In other Southeast Asian sampling sites, there is genomic evidence of flaviviruses (Phnom Penh bat virus) and bunyaviruses (Issyk-kul-Keterah virus), while there is serologic evidence of Nipah virus antibodies in E. spelaea from Malaysia [45-47]. Previous metagenomic studies on bats have revealed several novel viruses from a diverse group of viral families $[13,16,18,48,49]$. The virus families discovered in this study have been detected in several species of bats by conventional PCR and next generation sequencing, including adenoviruses [16,50,51], bunyaviruses [52-54], flaviviruses [55-57], herpesviruses $[16,49,58,59]$, paramyxoviruses [60-62], papillomaviruses $[14,16,63,64]$, parvoviruses $[12,59,65,66]$, picornaviruses [15,59,67], polyomaviruses [14,68-70], poxviruses [16,71,72] and reoviruses [73-76].

We reconstructed individual gene phylogenies for each of the above-mentioned virus families. In most phylogenies, our novel viral sequences of Eonycteris spelaea are clustered within a group of bat viruses from other genera, often from the same family (Pteropodidae), indicating circulation of these viruses among different bat species. Detection of novel viruses may not provide direct information on zoonotic capacity, but the generated sequence data can allow us to better understand the evolutionary history of these virus families and infer potential cross-species transmission [77]. For instance, our VP1 phylogeny of parvovirus indicates that bat parvoviruses are sister to murine and porcine parvoviruses, whereas the VP2 phylogeny shows bat parvoviruses are closely related to canine, feline and porcine parvoviruses. It is apparent that parvovirus is capable of infecting a broad host species, although further research is needed to understand how the virus jumps to different hosts.

Viruses exhibit specific tissue tropisms based on available cellular receptors and compatibility of the intracellular environment. Detection of these viruses depends on what tissue or sample type is being screened. Previous studies have indicated which viruses are more likely to be shed 
in feces (adenoviruses, astroviruses, parvoviruses, picornaviruses), urine (paramyxovirues), or tissues [60,78-81]. Receptors can be widely available, such as in paramyxovirus (CD46 in measles and sialic acid in Sendai virus) and picornavirus infections (ICAM-1 in Coxsackie virus), or narrowly restricted in adenovirus infections (integrin on monocytes) [82]. Due to limited commercial reagents and the difficulty of maintaining experimental colonies, little work has been done to characterize receptors and viral tissue preference in bats, though progress is being made in determining coronavirus tropism [83-85].

Consensus family level primers are used globally for virus biosurveillance and amplify the most conserved genomic region, usually the polymerase, but these primers may be of limited utility in detecting divergent strains [86]. Unbiased NGS reads will capture reads scattered across the virus genome, depending on the starting quantity of the sample and virus [10]. As sequencing reactions generate reads from all nucleic acids, reads can end up binned as unknown because there are no similar reads available in reference data sets (GenBank nucleotide and non-redundant RefSeq proteins). To minimize having unassigned reads, our approach used the program DIAMOND and the nr data set to only assign sequences that have homology to coding regions, eliminating false assignments of ribosomal RNA [34]. Our NGS sequencing of bat fecal and urine samples resulted in a low proportion of viral reads. This is common in metagenomic data sets where the majority of assigned reads were from the host, bacteria and viruses that infect plants, bacteria and insects [14]. These large data sets often provide low coverage across the genomes of viruses due to the host and bacterial background [87]. Interestingly, in our study, more viral reads were generated from the MiSeq Illumina than the HiSeq Illumina. Interestingly, retrovirus reads were much more common in the urine data set compared to the fecal data set. This may be caused by the comparatively low background in the urine.

In this study, we characterized the fecal and urine virome of Eonycteris spelaea, an ecologically important species [30]. The NGS data sets provided sequencing reads for 10 families of viruses that are known to infect mammals, providing segments to develop strain-specific assays to detect and quantify these viruses for future longitudinal studies. Recent research has demonstrated that co-roosting and colony size may be important in the generation of novel variants and in viral maintenance $[88,89]$. As this species roosts in large numbers, co-roosts with several other species of bats, and is widely distributed, it may be a candidate species to understand if virus diversity is based on phylogenetic relatedness, co-roosting partners or geographic separation. Additionally, with the sequencing of the full genome and the presence of a captive colony of bats at Duke-NUS Medical School, this will expand our capacity in understanding the genomics, infection and immunology of host-virus interactions using E. spelaea as the studied species [90].

Supplementary Materials: The following are available online at http://www.mdpi.com/1999-4915/11/3/ 250/s1, Figure S1: Phylogenetic relationships of the V4 gene sequences of adenovirus, inferred by using the maximum-likelihood method with the GTR+GAMMA model in RAxML; Figure S2: Phylogenetic relationships of the E and NS5 gene sequences of flavivirus, inferred by using the maximum-likelihood method with the GTR+GAMMA model in RAxML; Figure S3: Phylogenetic relationships of the E1 gene sequences of papillomavirus, inferred by using the maximum-likelihood method with the GTR+GAMMA model in RAxML; Figure S4: Phylogenetic relationships of the polyprotein and 3D gene sequences of picomavirus, inferred by using the maximum-likelihood method with the GTR+GAMMA model in RAxML; Figure S5: Phylogenetic relationships of the VP2 sequences of polyomavirus, inferred by using the maximum-likelihood method with the GTR+GAMMA model in RAxML.

Author Contributions: I.H.M., G.J.D.S., and L.W. conceived and designed the experiments; I.H.M., D.L.H.W., J.J. performed the experiments; I.H.M., J.J., V.G., S.M.-S., Y.C.F.S., and G.J.D.S. analyzed the data; V.G. and S.M.-S. contributed analysis tools; I.H.M., Y.C.F.S., and G.J.D.S. wrote the first draft paper with contributions from V.G. and S.M.-S.

Acknowledgments: This study was supported by the Duke-NUS Signature Research Program funded by the Ministry of Health, the National Medical Research Council (NMRC/BNIG/2005/2013), and the NUS-Global Asia Institute grant NIHA-2011-1-005, Singapore. L-FW was supported by grants NRF-CRP10-2012-05; NRF2016NRFMINDEF-NUS-DIRP/2015/05 from National Research Foundation and Ministry of Defence, Singapore. VG and SMS were supported by the A*STAR HEIDI programme (grant number H1699f0013), Singapore. IHM, JJ, YCFS, and GJDS were supported by contract HHSN272201400006C from the National Institute of Allergy and Infectious 
Disease, National Institutes of Health, US Department of Health and Human Services, USA. We would like to thank KL Okihara for her assistance in lab work and D. Zaini and X. Song for field collections.

Conflicts of Interest: The authors declare no conflict of interest. The founding sponsors had no role in the design of the study; in the collection, analyses, or interpretation of data; in the writing of the manuscript, and in the decision to publish the results.

\section{References}

1. Li, C.X.; Shi, M.; Tian, J.H.; Lin, X.D.; Kang, Y.J.; Chen, L.J.; Qin, X.C.; Xu, J.; Holmes, E.C.; Zhang, Y.Z. Unprecedented genomic diversity of RNA viruses in arthropods reveals the ancestry of negative-sense RNA viruses. Elife 2015, 4. [CrossRef] [PubMed]

2. Beerenwinkel, N.; Gunthard, H.F.; Roth, V.; Metzner, K.J. Challenges and opportunities in estimating viral genetic diversity from next-generation sequencing data. Front Microbiol. 2012, 3, 329. [CrossRef] [PubMed]

3. VanDevanter, D.R.; Warrener, P.; Bennett, L.; Schultz, E.R.; Coulter, S.; Garber, R.L.; Rose, T.M. Detection and analysis of diverse herpesviral species by consensus primer PCR. J. Clin. Microbiol. 1996, 34, 1666-1671. [PubMed]

4. Vijgen, L.; Moes, E.; Keyaerts, E.; Li, S.; Van Ranst, M. A pancoronavirus RT-PCR assay for detection of all known coronaviruses. Methods Mol. Biol. 2008, 454, 3-12. [CrossRef] [PubMed]

5. Tong, S.; Chern, S.W.; Li, Y.; Pallansch, M.A.; Anderson, L.J. Sensitive and broadly reactive reverse transcription-PCR assays to detect novel paramyxoviruses. J. Clin. Microbiol. 2008, 46, 2652-2658. [CrossRef] [PubMed]

6. Prachayangprecha, S.; Schapendonk, C.M.; Koopmans, M.P.; Osterhaus, A.D.; Schurch, A.C.; Pas, S.D.; Van der Eijk, A.A.; Poovorawan, Y.; Haagmans, B.L.; Smits, S.L. Exploring the potential of next-generation sequencing in detection of respiratory viruses. J. Clin. Microbiol. 2014, 52, 3722-3730. [CrossRef] [PubMed]

7. Volpicella, M.; Leoni, C.; Costanza, A.; Fanizza, I.; Placido, A.; Ceci, L.R. Genome walking by next generation sequencing approaches. Biology 2012, 1, 495-507. [CrossRef] [PubMed]

8. Marston, D.A.; McElhinney, L.M.; Ellis, R.J.; Horton, D.L.; Wise, E.L.; Leech, S.L.; David, D.; De Lamballerie, X.; Fooks, A.R. Next generation sequencing of viral RNA genomes. BMC Genomics 2013, 14, 444. [CrossRef] [PubMed]

9. Bialasiewicz, S.; McVernon, J.; Nolan, T.; Lambert, S.B.; Zhao, G.; Wang, D.; Nissen, M.D.; Sloots, T.P. Detection of a divergent Parainfluenza 4 virus in an adult patient with influenza like illness using next-generation sequencing. BMC Infect. Dis. 2014, 14, 275. [CrossRef] [PubMed]

10. Radford, A.D.; Chapman, D.; Dixon, L.; Chantrey, J.; Darby, A.C.; Hall, N. Application of next-generation sequencing technologies in virology. J. Gen. Virol. 2012, 93, 1853-1868. [CrossRef]

11. Matranga, C.B.; Andersen, K.G.; Winnicki, S.; Busby, M.; Gladden, A.D.; Tewhey, R.; Stremlau, M.; Berlin, A.; Gire, S.K.; England, E.; et al. Enhanced methods for unbiased deep sequencing of Lassa and Ebola RNA viruses from clinical and biological samples. Genome Biol. 2014, 15, 519. [CrossRef]

12. Ge, X.; Li, Y.; Yang, X.; Zhang, H.; Zhou, P.; Zhang, Y.; Shi, Z. Metagenomic analysis of viruses from bat fecal samples reveals many novel viruses in insectivorous bats in China. J. Virol. 2012, 86, 4620-4630. [CrossRef] [PubMed]

13. He, B.; Li, Z.; Yang, F.; Zheng, J.; Feng, Y.; Guo, H.; Li, Y.; Wang, Y.; Su, N.; Zhang, F.; et al. Virome profiling of bats from Myanmar by metagenomic analysis of tissue samples reveals more novel Mammalian viruses. PLoS ONE 2013, 8, e61950. [CrossRef]

14. Wang, J.; Moore, N.E.; Murray, Z.L.; McInnes, K.; White, D.J.; Tompkins, D.M.; Hall, R.J. Discovery of novel virus sequences in an isolated and threatened bat species, the New Zealand lesser short-tailed bat (Mystacina tuberculata). J. Gen. Virol. 2015, 96, 2442-2452. [CrossRef] [PubMed]

15. Li, L.; Victoria, J.G.; Wang, C.; Jones, M.; Fellers, G.M.; Kunz, T.H.; Delwart, E. Bat guano virome: Predominance of dietary viruses from insects and plants plus novel mammalian viruses. J. Virol. 2010, 84, 6955-6965. [CrossRef] [PubMed]

16. Baker, K.S.; Leggett, R.M.; Bexfield, N.H.; Alston, M.; Daly, G.; Todd, S.; Tachedjian, M.; Holmes, C.E.; Crameri, S.; Wang, L.F.; et al. Metagenomic study of the viruses of African straw-coloured fruit bats: Detection of a chiropteran poxvirus and isolation of a novel adenovirus. Virology 2013, 441, 95-106. [CrossRef] [PubMed] 
17. Yinda, C.K.; Zeller, M.; Conceicao-Neto, N.; Maes, P.; Deboutte, W.; Beller, L.; Heylen, E.; Ghogomu, S.M.; Van Ranst, M.; Matthijnssens, J. Novel highly divergent reassortant bat rotaviruses in Cameroon, without evidence of zoonosis. Sci. Rep. 2016, 6, 34209. [CrossRef] [PubMed]

18. Yuan, L.; Li, M.; Li, L.; Monagin, C.; Chmura, A.A.; Schneider, B.S.; Epstein, J.H.; Mei, X.; Shi, Z.; Daszak, P.; et al. Evidence for retrovirus and paramyxovirus infection of multiple bat species in china. Viruses 2014, 6, 2138-2154. [CrossRef] [PubMed]

19. He, B.; Feng, Y.; Zhang, H.; Xu, L.; Yang, W.; Zhang, Y.; Li, X.; Tu, C. Filovirus RNA in fruit bats, China. Emerg. Infect. Dis. 2015, 21, 1675-1677. [CrossRef] [PubMed]

20. Calisher, C.H.; Childs, J.E.; Field, H.E.; Holmes, K.V.; Schountz, T. Bats: Important reservoir hosts of emerging viruses. Clin. Microbiol. Rev. 2006, 19, 531-545. [CrossRef]

21. Hutson, A.M.; Mickleburgh, S.P. Microchiropteran Bats: Global Status Survey and Conservation Action Plan; IUCN: Gland, Switzerland, 2001; Volume 56.

22. Kunz, T.H.; Fenton, M.B. Bat Ecology; University of Chicago Press: Chicago, IL, USA, 2005.

23. Thomas, S.P.; Suthers, R.A. The physiology and energetics of bat flight. J. Exp. Biol. 1972, 57, 317-335.

24. Cooke, M.S.; Evans, M.D.; Dizdaroglu, M.; Lunec, J. Oxidative DNA damage: Mechanisms, mutation, and disease. FASEB J. 2003, 17, 1195-1214. [CrossRef] [PubMed]

25. Ahn, M.; Cui, J.; Irving, A.T.; Wang, L.F. Unique loss of the PYHIN Gene family in bats amongst mammals: Implications for Inflammasome sensing. Sci. Rep. 2016, 6, 21722. [CrossRef]

26. Zhou, P.; Tachedjian, M.; Wynne, J.W.; Boyd, V.; Cui, J.; Smith, I.; Cowled, C.; Ng, J.H.; Mok, L.; Michalski, W.P.; et al. Contraction of the type I IFN locus and unusual constitutive expression of IFN-alpha in bats. Proc. Natl. Acad. Sci. USA 2016, 113, 2696-2701. [CrossRef] [PubMed]

27. Xie, J.; Li, Y.; Shen, X.; Goh, G.; Zhu, Y.; Cui, J.; Wang, L.F.; Shi, Z.L.; Zhou, P. Dampened STING-dependent interferon activation in bats. Cell Host Microbe 2018, 23, 297-301. [CrossRef] [PubMed]

28. Francis, C.; Rosell-Ambal, G.; Tabaranza, B.; Carino, P.; Helgen, K.; Molur, S.; Srinivasulu, C. Eonycteris Spelaea. Available online: http://dx.doi.org/10.2305/IUCN.UK.2008.RLTS.T7787A12850087.en (accessed on 4 June 2018).

29. Bumrungsri, S.; Sripaoraya, E.; Chongsiri, T.; Sridith, K.; Racey, P.A. The pollination ecology of durian (Durio zibethinus, Bombacaceae) in southern Thailand. J. Trop. Ecol. 2009, 25, 85-92. [CrossRef]

30. Bumrungsri, S.; Lang, D.; Harrower, C.; Sripaoraya, E.; Kitpipit, K.; Racey, P.A. The dawn bat, Eonycteris spelaea Dobson (Chiroptera: Pteropodidae) feeds mainly on pollen of economically important food plants in Thailand. Acta Chiropterol. 2013, 15, 95-104. [CrossRef]

31. Mendenhall, I.H.; Borthwick, S.; Neves, E.S.; Low, D.; Linster, M.; Liang, B.; Skiles, M.; Jayakumar, J.; Han, H.; Gunalan, V.; et al. Identification of a lineage D Betacoronavirus in Cave Nectar Bats (Eonycteris spelaea) in Singapore and an overview of lineage D reservoir ecology in SE Asian Bats. Transbound Emerg. Dis. 2017, 64, 1790-1800. [CrossRef]

32. Andrews, S. FastQC. Available online: http://www.bioinformatics.bbsrc.ac.uk/projects/fastqc/ (accessed on 17 September 2015).

33. Bolger, A.M.; Lohse, M.; Usadel, B. Trimmomatic: A flexible trimmer for Illumina sequence data. Bioinformatics 2014, 30, 2114-2120. [CrossRef]

34. Buchfink, B.; Xie, C.; Huson, D.H. Fast and sensitive protein alignment using DIAMOND. Nat. Methods 2015, 12, 59-60. [CrossRef]

35. Huson, D.H.; Auch, A.F.; Qi, J.; Schuster, S.C. MEGAN analysis of metagenomic data. Genome Res. 2007, 17,377-386. [CrossRef] [PubMed]

36. Wellehan, J.F., Jr.; Childress, A.L.; Marschang, R.E.; Johnson, A.J.; Lamirande, E.W.; Roberts, J.F.; Vickers, M.L.; Gaskin, J.M.; Jacobson, E.R. Consensus nested PCR amplification and sequencing of diverse reptilian, avian, and mammalian orthoreoviruses. Vet. Microbiol. 2009, 133, 34-42. [CrossRef]

37. Kearse, M.; Moir, R.; Wilson, A.; Stones-Havas, S.; Cheung, M.; Sturrock, S.; Buxton, S.; Cooper, A.; Markowitz, S.; Duran, C.; et al. Geneious Basic: An integrated and extendable desktop software platform for the organization and analysis of sequence data. Bioinformatics 2012, 28, 1647-1649. [CrossRef] [PubMed]

38. Bininda-Emonds, O.R. transAlign: Using amino acids to facilitate the multiple alignment of protein-coding DNA sequences. BMC Bioinformat. 2005, 6, 156. [CrossRef] [PubMed]

39. Katoh, K.; Standley, D.M. MAFFT multiple sequence alignment software version 7: Improvements in performance and usability. Molec. Biol. Evol. 2013, 30, 772-780. [CrossRef] [PubMed] 
40. Price, M.N.; Dehal, P.S.; Arkin, A.P. FastTree: Computing large minimum evolution trees with profiles instead of a distance matrix. Molec. Biol. Evol. 2009, 26, 1641-1650. [CrossRef] [PubMed]

41. Stamatakis, A. RAxML version 8: A tool for phylogenetic analysis and post-analysis of large phylogenies. Bioinformatics 2014, 30, 1312-1313. [CrossRef]

42. Bonning, B.C.; Miller, W.A. Dicistroviruses. Ann. Rev. Entomol. 2010, 55, 129-150. [CrossRef]

43. Laing, E.D.; Mendenhall, I.H.; Linster, M.; Low, D.H.W.; Chen, Y.; Yan, L.; Sterling, S.L.; Borthwick, S.; Neves, E.S.; Lim, J.S.L.; et al. Serologic evidence of fruit bat exposure to filoviruses, Singapore, 2011-2016. Emerg. Infect. Dis. 2018, 24, 114-117. [CrossRef] [PubMed]

44. Mendenhall, I.H.; Skiles, M.M.; Neves, E.S.; Borthwick, S.A.; Low, D.H.W.; Liang, B.; Lee, B.P.Y.; Su, Y.C.F.; Smith, G.J.D. Influence of age and body condition on astrovirus infection of bats in Singapore: An evolutionary and epidemiological analysis. One Health 2017, 4, 27-33. [CrossRef]

45. Queen, K.; Shi, M.; Anderson, L.J.; Tong, S. Other bt-borne viruses. In Bats and Viruses; Wang, L.-F., Cowled, C., Eds.; John Wiley \& Sons, Inc.: Hoboken, NY, USA, 2015; Chapter 9; pp. 217-247.

46. Yang, X.-L.; Zhang, Y.-Z.; Jiang, R.-D.; Guo, H.; Zhang, W.; Li, B.; Wang, N.; Wang, L.; Waruhiu, C.; Zhou, J.-H. Genetically diverse filoviruses in Rousettus and Eonycteris spp. bats, China, 2009 and 2015. Emerg. Infect. Dis. 2017, 23, 482. [CrossRef]

47. Yob, J.M.; Field, H.; Rashdi, A.M.; Morrissy, C.; Van der Heide, B.; Rota, P.; Bin Adzhar, A.; White, J.; Daniels, P.; Jamaluddin, A.; et al. Nipah virus infection in bats (order Chiroptera) in peninsular Malaysia. Emerg. Infect. Dis. 2001, 7, 439-441. [CrossRef] [PubMed]

48. Reuter, G.; Pankovics, P.; Gyongyi, Z.; Delwart, E.; Boros, A. Novel dicistrovirus from bat guano. Arch. Virol. 2014, 159, 3453-3456. [CrossRef] [PubMed]

49. Dacheux, L.; Cervantes-Gonzalez, M.; Guigon, G.; Thiberge, J.M.; Vandenbogaert, M.; Maufrais, C.; Caro, V.; Bourhy, H. A preliminary study of viral metagenomics of French bat species in contact with humans: Identification of new mammalian viruses. PloS ONE 2014, 9, e87194. [CrossRef] [PubMed]

50. Maeda, K.; Hondo, E.; Terakawa, J.; Kiso, Y.; Nakaichi, N.; Endoh, D.; Sakai, K.; Morikawa, S.; Mizutani, T. Isolation of novel adenovirus from fruit bat (Pteropus dasymallus yayeyamae). Emerg. Infect. Dis. 2008, 14, 347-349. [CrossRef] [PubMed]

51. Li, Y.; Ge, X.; Zhang, H.; Zhou, P.; Zhu, Y.; Zhang, Y.; Yuan, J.; Wang, L.F.; Shi, Z. Host range, prevalence, and genetic diversity of adenoviruses in bats. J. Virol. 2010, 84, 3889-3897. [CrossRef] [PubMed]

52. Osborne, J.; Rupprecht, C.; Olson, J.; Ksiazek, T.; Rollin, P.; Niezgoda, M.; Goldsmith, C.; An, U.; Nichol, S. Isolation of Kaeng Khoi virus from dead Chaerephon plicata bats in Cambodia. J. Gen. Virol. 2003, 84, 2685-2689. [CrossRef] [PubMed]

53. Weiss, S.; Witkowski, P.T.; Auste, B.; Nowak, K.; Weber, N.; Fahr, J.; Mombouli, J.-V.; Wolfe, N.D.; Drexler, J.F.; Drosten, C. Hantavirus in bat, sierra leone. Emerg. Infect. Dis. 2012, 18, 159. [CrossRef]

54. Mourya, D.; Yadav, P.; Basu, A.; Shete, A.; Patil, D.; Zawar, D.; Majumdar, T.; Kokate, P.; Sarkale, P.; Raut, C. Malsoor virus, a novel bat Phlebovirus is closely related to STFS and Heartland viruses. J. Virol. 2014, 88, 3605-3609. [CrossRef] [PubMed]

55. De Lamballerie, X.; Crochu, S.; Billoir, F.; Neyts, J.; De Micco, P.; Holmes, E.C.; Gould, E.A. Genome sequence analysis of Tamana bat virus and its relationship with the genus Flavivirus. J. Gen. Virol. 2002, 83, 2443-2454. [CrossRef]

56. Tajima, S.; Takasaki, T.; Matsuno, S.; Nakayama, M.; Kurane, I. Genetic characterization of Yokose virus, a flavivirus isolated from the bat in Japan. Virology 2005, 332, 38-44. [CrossRef] [PubMed]

57. Salaun, J.; Klein, J.; Hebrard, G. A new virus, Phnom-Penh bat virus, isolated in Cambodia from a short-nosed fruit bat, Cynopterus brachyotis angulatus. Ann. Microbiol. (Inst. Pasteur) 1974, 125, 485-495.

58. Janoska, M.; Vidovszky, M.; Molnar, V.; Liptovszky, M.; Harrach, B.; Benko, M. Novel adenoviruses and herpesviruses detected in bats. Vet. J. 2011, 189, 118-121. [CrossRef] [PubMed]

59. Wu, Z.; Ren, X.; Yang, L.; Hu, Y.; Yang, J.; He, G.; Zhang, J.; Dong, J.; Sun, L.; Du, J.; et al. Virome analysis for identification of novel mammalian viruses in bat species from Chinese provinces. J. Virol. 2012, 86, 10999-11012. [CrossRef] [PubMed]

60. Drexler, J.F.; Corman, V.M.; Muller, M.A.; Maganga, G.D.; Vallo, P.; Binger, T.; Gloza-Rausch, F.; Cottontail, V.M.; Rasche, A.; Yordanov, S.; et al. Bats host major mammalian paramyxoviruses. Nat. Commun. 2012, 3, 796. [CrossRef] [PubMed] 
61. Kurth, A.; Kohl, C.; Brinkmann, A.; Ebinger, A.; Harper, J.A.; Wang, L.F.; Muhldorfer, K.; Wibbelt, G. Novel paramyxoviruses in free-ranging European bats. PLoS ONE 2012, 7, e38688. [CrossRef] [PubMed]

62. Anderson, D.E.; Marsh, G.A. Bat Paramyxoviruses. In Bats and Viruses; Wang, L.-F., Cowled, C., Eds.; John Wiley \& Sons, Inc.: Hoboken, NY, USA, 2015; Chapter 4; pp. 99-126.

63. Tse, H.; Tsang, A.K.L.; Tsoi, H.W.; Leung, A.S.P.; Ho, C.C.; Lau, S.K.P.; Woo, P.C.Y.; Yuen, K.Y. Identification of a Novel Bat Papillomavirus by Metagenomics. PLoS ONE 2012, 7, e43986. [CrossRef] [PubMed]

64. Garcia-Perez, R.; Gottschling, M.; Wibbelt, G.; Bravo, I.G. Multiple evolutionary origins of bat papillomaviruses. Vet. Microbiol. 2013, 165, 51-60. [CrossRef]

65. Li, Y.; Ge, X.; Hon, C.C.; Zhang, H.; Zhou, P.; Zhang, Y.; Wu, Y.; Wang, L.F.; Shi, Z. Prevalence and genetic diversity of adeno-associated viruses in bats from China. J. Gen. Virol. 2010, 91, 2601-2609. [CrossRef] [PubMed]

66. Canuti, M.; Eis-Huebinger, A.M.; Deijs, M.; De Vries, M.; Drexler, J.F.; Oppong, S.K.; Muller, M.A.; Klose, S.M.; Wellinghausen, N.; Cottontail, V.M.; et al. Two novel parvoviruses in frugivorous New and Old World bats. PLoS ONE 2011, 6, e29140. [CrossRef]

67. Lau, S.K.; Woo, P.C.; Lai, K.K.; Huang, Y.; Yip, C.C.; Shek, C.T.; Lee, P.; Lam, C.S.; Chan, K.H.; Yuen, K.Y. Complete genome analysis of three novel picornaviruses from diverse bat species. J. Virol. 2011, 85, 8819-8828. [CrossRef] [PubMed]

68. Fagrouch, Z.; Sarwari, R.; Lavergne, A.; Delaval, M.; De Thoisy, B.; Lacoste, V.; Verschoor, E.J. Novel polyomaviruses in South American bats and their relationship to other members of the family Polyomaviridae. J. Gen. Virol. 2012, 93, 2652-2657. [CrossRef] [PubMed]

69. Misra, V.; Dumonceaux, T.; Dubois, J.; Willis, C.; Nadin-Davis, S.; Severini, A.; Wandeler, A.; Lindsay, R.; Artsob, H. Detection of polyoma and corona viruses in bats of Canada. J. Gen. Virol. 2009, 90, 2015-2022. [CrossRef] [PubMed]

70. Tao, Y.; Shi, M.; Conrardy, C.; Kuzmin, I.V.; Recuenco, S.; Agwanda, B.; Alvarez, D.A.; Ellison, J.A.; Gilbert, A.T.; Moran, D. Discovery of diverse polyomaviruses in bats and the evolutionary history of the Polyomaviridae. J. Gen. Virol. 2013, 94, 738-748. [CrossRef] [PubMed]

71. Emerson, G.L.; Nordhausen, R.; Garner, M.M.; Huckabee, J.R.; Johnson, S.; Wohrle, R.D.; Davidson, W.B.; Wilkins, K.; Li, Y.; Doty, J.B. Novel poxvirus in big brown bats, northwestern United States. Emerg. Infect. Dis. 2013, 19, 1002. [CrossRef] [PubMed]

72. O’Dea, M.A.; Tu, S.-L.; Pang, S.; De Ridder, T.; Jackson, B.; Upton, C. Genomic characterization of a novel poxvirus from a flying fox: Evidence for a new genus? J. Gen. Virol. 2016, 97, 2363-2375. [CrossRef]

73. Pritchard, L.I.; Chua, K.B.; Cummins, D.; Hyatt, A.; Crameri, G.; Eaton, B.T.; Wang, L.F. Pulau virus; A new member of the Nelson Bay orthoreovirus species isolated from fruit bats in Malaysia. Arch. Virol. 2006, 151, 229-239. [CrossRef]

74. Thalmann, C.M.; Cummins, D.M.; Yu, M.; Lunt, R.; Pritchard, L.I.; Hansson, E.; Crameri, S.; Hyatt, A.; Wang, L.F. Broome virus, a new fusogenic Orthoreovirus species isolated from an Australian fruit bat. Virology 2010, 402, 26-40. [CrossRef] [PubMed]

75. Kohl, C.; Kurth, A. Bat Reoviruses. In Bats and Viruses; Wang, L.-F., Cowled, C., Eds.; John Wiley \& Sons, Inc.: Hoboken, NY, USA, 2015; Chapter 8; pp. 203-215.

76. Yang, X.L.; Tan, B.; Wang, B.; Li, W.; Wang, N.; Luo, C.M.; Wang, M.N.; Zhang, W.; Li, B.; Peng, C.; et al. Isolation and identification of bat viruses closely related to human, porcine, and mink orthoreoviruses. J. Gen. Virol. 2015, 96, 3525-3531. [CrossRef]

77. Corman, V.M.; Baldwin, H.J.; Tateno, A.F.; Zerbinati, R.M.; Annan, A.; Owusu, M.; Nkrumah, E.E.; Maganga, G.D.; Oppong, S.; Adu-Sarkodie, Y. Evidence for an ancestral association of human coronavirus 229E with bats. J. Virol. 2015, 89, 11858-11870. [CrossRef] [PubMed]

78. Hayman, D.T.; Bowen, R.A.; Cryan, P.M.; McCracken, G.F.; O'Shea, T.J.; Peel, A.J.; Gilbert, A.; Webb, C.T.; Wood, J.L. Ecology of zoonotic infectious diseases in bats: Current knowledge and future directions. Zoonoses Public Health 2013, 60, 2-21. [CrossRef]

79. Drexler, J.F.; Corman, V.M.; Wegner, T.; Tateno, A.F.; Zerbinati, R.M.; Gloza-Rausch, F.; Seebens, A.; Muller, M.A.; Drosten, C. Amplification of emerging viruses in a bat colony. Emerg. Infect. Dis. 2011, 17, 449-456. [CrossRef] 
80. Drexler, J.F.; Geipel, A.; Konig, A.; Corman, V.M.; Van Riel, D.; Leijten, L.M.; Bremer, C.M.; Rasche, A.; Cottontail, V.M.; Maganga, G.D.; et al. Bats carry pathogenic hepadnaviruses antigenically related to hepatitis B virus and capable of infecting human hepatocytes. Proc. Natl. Acad. Sci. USA 2013, 110, 16151-16156. [CrossRef] [PubMed]

81. Drexler, J.F.; Seelen, A.; Corman, V.M.; Fumie Tateno, A.; Cottontail, V.; Melim Zerbinati, R.; Gloza-Rausch, F.; Klose, S.M.; Adu-Sarkodie, Y.; Oppong, S.K.; et al. Bats worldwide carry hepatitis E virus-related viruses that form a putative novel genus within the family Hepeviridae. J. Virol. 2012, 86, 9134-9147. [CrossRef] [PubMed]

82. Schneider-Schaulies, J. Cellular receptors for viruses: Links to tropism and pathogenesis. J. Gen. Virol. 2000, 81, 1413-1429. [CrossRef]

83. Woo, P.C.; Lau, S.K.; Chen, Y.; Wong, E.Y.; Chan, K.-H.; Chen, H.; Zhang, L.; Xia, N.; Yuen, K.-Y. Rapid detection of MERS coronavirus-like viruses in bats: Pote1ntial for tracking MERS coronavirus transmission and animal origin. Emerg. Microb. Infect. 2018, 7, 18. [CrossRef]

84. Widagdo, W.; Begeman, L.; Schipper, D.; Van Run, P.R.; Cunningham, A.A.; Kley, N.; Reusken, C.B.; Haagmans, B.L.; Van den Brand, J.M. Tissue distribution of the MERS-coronavirus receptor in bats. Sci. Rep. 2017, 7, 1193. [CrossRef]

85. Letko, M.; Miazgowicz, K.; McMinn, R.; Seifert, S.N.; Sola, I.; Enjuanes, L.; Carmody, A.; Van Doremalen, N.; Munster, V. Adaptive evolution of MERS-CoV to Species variation in DPP4. Cell Rep. 2018, 24, 1730-1737. [CrossRef]

86. Rose, T.M.; Schultz, E.R.; Henikoff, J.G.; Pietrokovski, S.; McCallum, C.M.; Henikoff, S. Consensus-degenerate hybrid oligonucleotide primers for amplification of distantly related sequences. Nucleic Acids Res. 1998, 26, 1628-1635. [CrossRef] [PubMed]

87. Lambert, C.; Braxton, C.; Charlebois, R.; Deyati, A.; Duncan, P.; La Neve, F.; Malicki, H.; Ribrioux, S.; Rozelle, D.; Michaels, B. Considerations for Optimization of High-throughput sequencing bioinformatics pipelines for virus detection. Viruses 2018, 10, 528. [CrossRef]

88. Hu, B.; Zeng, L.-P.; Yang, X.-L.; Ge, X.-Y.; Zhang, W.; Li, B.; Xie, J.-Z.; Shen, X.-R.; Zhang, Y.-Z.; Wang, N. Discovery of a rich gene pool of bat SARS-related coronaviruses provides new insights into the origin of SARS coronavirus. PLoS Pathog. 2017, 13, e1006698. [CrossRef] [PubMed]

89. Hayman, D.T. Biannual birth pulses allow filoviruses to persist in bat populations. Proc. Biol. Sci. Royal Soc. 2015, 282, 20142591. [CrossRef] [PubMed]

90. Wen, M.; Ng, J.H.; Zhu, F.; Chionh, Y.T.; Chia, W.N.; Mendenhall, I.H.; Lee, B.P.-H.; Irving, A.T.; Wang, L.-F. Exploring the genome and transcriptome of the cave nectar bat Eonycteris spelaea with PacBio long-read sequencing. GigaScience 2018, 7, giy116. [CrossRef] [PubMed] 